\title{
Pengolahan Fasa untuk Mendapatkan Model Tinggi Permukaan Dijital (DEM) pada Radar Apertur Sintetik Interferometri (INSAR) Data Satelit
}

\author{
Ishak Hanafiah Ismullah \\ Departemen Teknik Geodesi \\ Fakultas Teknik Sipil \& Perencanaan - Institut Teknologi Bandung
}

\begin{abstract}
Abstrak. Dibandingkan dengan sensor optis, teknologi radar dapat dikatakan baru dimulai. Pemetaan dengan sensor optis, terutama dengan metoda Fotogrametri menunjukkan hasil geometri yang sangat baik, akan tetapi kendala utamanya adalah awan, dan ini merupakan kelemahan utama pada teknik Fotogrametri. Indonesia merupakan negara tropis yang kondisi awannya sangat dominan dan bahkan sebagian areanya tertutup awan hampir sepanjang tahun. Pencitraan radar mempunyai kelebihan, yaitu mampu menembus awan, kabut ataupun hujan. Karena sifatnya aktif, maka teknik ini tidak tergantung pada matahari, dan dapat dioperasikan baik siang maupun malam. Adanya satelit yang membawa sensor radar seperti ERS, RADARSAT, JERS ataupun ENVISAT, membuka peluang untuk diolah secara interferometri dengan mengolah fasa dari sinyal balik yang diterima sistim radar pada satelit tersebut. Tulisan ini mencoba menunjukkan bagaimana mengolah fasa dari data satelit radar, khususnya ERS1 dan ERS2. Disamping itu juga dilakukan validasi hasilnya dengan membandingkan dengan teknik Fotogrametri dijital. Wilayah yang dipilih adalah sekitar Gunung Cikurai dan Gunung Papandayan Jawa Barat.
\end{abstract}

Kata kunci: geo-coding; interferogram; model tinggi permukaan dijital-DEM; radar apertur sintetik interferometri-INSAR.

\begin{abstract}
Comparing to optical sensors, radar technology has only just begun. Mapping by optical sensors, especially with Photogrammetric methode shows a very good result, but the main constraint is cloud cover conditions, and this was the weakness point of the Photogrammetric techniques. Indonesia is a tropical country which has dominant cloud coverage, and some of the area has cloud cover almost all year long. Radar imaging has some advantages e.q. sun independence, cloud penetration etc. Active systems in ERS1, ERS2, RADARSAT, JERS, and ENVISAT make possible to do interferometric processing. This paper try to explain how to process phase information from radar satellite data especially from ERS1 and ERS2. The result has been compared with the Digital Photogrammetric technigue, for Papandayan and Cikurai vulcano, West Java.
\end{abstract}

Keywords: digital elevation model-DEM; geo-coding; interferogram; synthetic aperture radar interferometry-INSAR. 
